\title{
Walk with the Wind
}

\author{
Justin A. Joyce The New School
}

\begin{abstract}
Recalling the insurrectionary violence that descended upon the US Capitol on 6 January 2021, reflecting on the baser instincts left unchecked in America by an absence of common communication and a paradigmatic shift in our media apparatuses, Justin A. Joyce introduces the seventh volume of James Baldwin Review.
\end{abstract}

Keywords: James Baldwin, 2020 election, DC insurrection, Donald Trump, Abraham Lincoln, Joe Biden, No Name in the Street, social media 
The weight of this sad time we must obey, Speak what we feel, not what we ought to say. The oldest hath borne most; we that are young Shall never see so much, nor live so long.

William Shakespeare, King Lear ${ }^{1}$

People who treat other people as less than human must not be surprised when the bread they have cast on the waters comes floating back to them, poisoned.

James Baldwin, No Name in the Street ${ }^{2}$

$\mathrm{I}^{\mathrm{n}}$

$\mathrm{n}$ the prologue to his 1998 memoir Walking with the Wind, Congressman and civil rights icon John Lewis tells a remarkable story from his childhood about persistence and the power of a group working together. The story concerns a windstorm that rose up on a four-year-old Lewis and some fourteen playmates on a Saturday afternoon in Alabama, quickly gathering strength and forcing them to shelter in his Aunt Sevena's rather modest house. Terribly frightened, the previously boisterous children huddled together, suddenly very quiet as the winds howled. Sevena, the only adult present, was frightened too, Lewis recalls, as the storm grew louder still, shook and swayed the house, and began to lift it from its foundation. At Sevena's prudent instruction, the children gathered hands and marched toward that lifting corner, weighing down the house, bolstering it against the power of the wind that threatened its integrity. When the wind shifted, their collective presence was required to hold down a different section of the trembling house. This continued, Lewis reports, "back and forth, fifteen children walking with the wind, holding that trembling house down with the weight of our small bodies."

Recalling the story more than fifty years later, Lewis employs it as an analogy for the American struggle:

It has struck me more than once over those many years that our society is not unlike the children in that house, rocked again and again by the winds of one storm or another, the walls around us seeming at times as if they might fly apart ... But the people of conscience never left the house. They never ran away. They stayed, they came together and they did the best they could, clasping hands and moving toward the corner of the house that was the weakest.

And then another corner would lift, and we would go there ... Children holding hands, walking with the wind. That is America to me. ${ }^{4}$

It's an inspiring story and a powerful metaphor, no doubt. But I'm worried this tale may no longer cohere with the America we have seen of late. For what happens when the winds that threaten to tear the house apart come not from without, but from the bellicose bullies among these proverbial playmates? How do we walk with them? If the people of conscience let go their hold upon other hands, leave the house and run away, will there be enough walkers left to withstand the winds? 
If we can't stay together and we don't do the best we can, will our walking adrift to separate corners still hold the house together? If our responses to the inevitable winds evince an absence of decency, are devoid of any dignity, utterly bereft of any sense of brotherhood, which way do we walk then?

Despite these misgivings, I've chosen to open with Lewis's tale because I'm a fan of unifying metaphors. Not just within an ideal public sphere wherein we all work toward a common goal, but also within a single piece of writing. A written journey, if you will, whereby we together-the writer and the reader-travel along a path bestrewn with consistent rhetorical reminders of the theme that ties us together on our journey. Ever the traveler, Baldwin knew about such journeys. Writing to his agent, Jay Acton, in 1979, he reveals that journeys are often themselves revelatory: "I am saying that a journey is called that because you cannot know what you will discover on the journey, what you will do with what you find, or what you find will do to you." 5

I'd like to take us on such a journey, to traverse together the written page, but I'll admit this desire is somewhat self-centered because I am also searching for something on this journey. As Toni Morrison has noted, beyond the deadlines or the obligations, writing is occasionally the best way to find an answer:

Sometimes you're nudged; and sometimes you're just searching. To make the writing interesting to me. It's not just writing. It's, "I don't know what this means." But I have to find out. And I have to explore all the characters' attitudes and so on. I got to know. And the only way I can know, and own what I know, is to write it. And then let you read it. So we both know. ${ }^{6}$

I'm hoping we find not only a metaphor, but also that together we find hope. Along the way I'm trusting as well that I can find my own "better angels," such as those Lincoln implored when he closed his first inaugural on the eve of civil war with an oft-quoted call for unity:

We are not enemies, but friends. We must not be enemies. Though passion may have strained, it must not break our bonds of affection ... when again touched, as surely they will be, by the better angels of our nature.?

Lincoln, though, was hardly the last to call for unity in a bitterly divided nation. The sentiments appear with predictable regularity seemingly every time a group of entitled white men are enabled to run roughshod over the pillars of decency, decorum, and dignity that underlie our democracy-though these high-minded calls are notably absent when people of color in this nation call for something as basic as the respect of their fundamental rights. A mere fourteen days after the US Capitol was attacked, the "better angels" of Lincoln were explicitly invoked in President Biden's call for forgiveness and unity during his own inauguration. Something about unity, "hope," and the "better angels" of our nature, then, is what I am supposed to be saying. But that's not, in truth, what I'm feeling. 


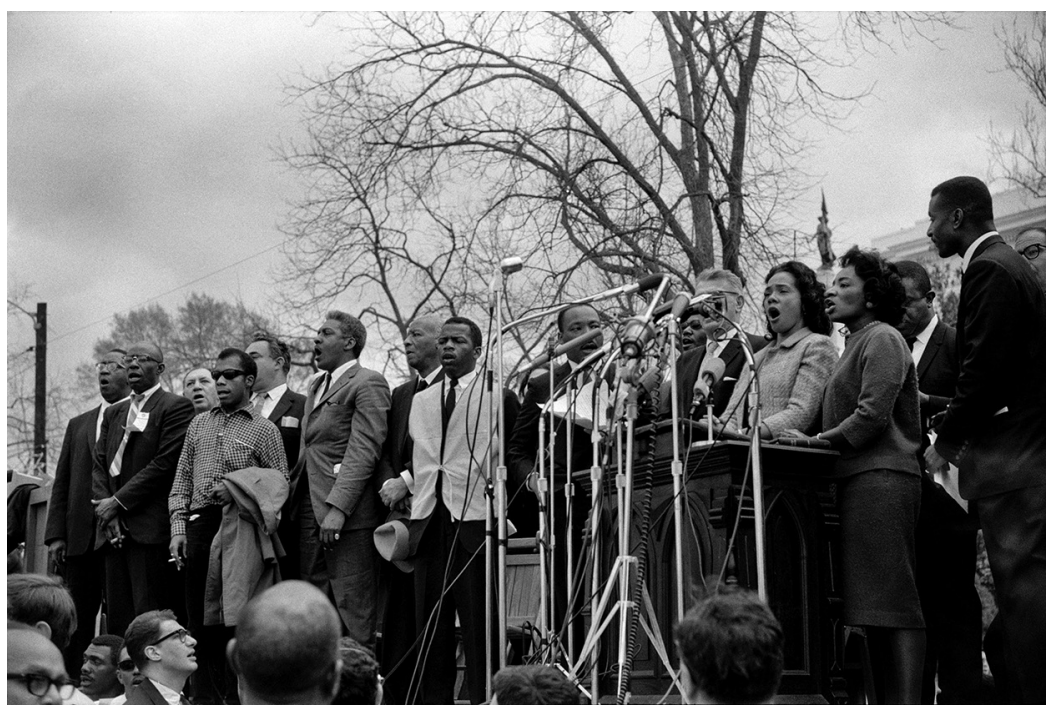

Figure 1 Selma to Montgomery March, 1965: James Baldwin third from left in front row; John Lewis (then President of SNCC) sixth from left in front (Photograph by Stephen F. Somerstein/Getty Images)

I'm not ready to count those denying truth and sowing division for partisanship or profit as my "enemies," per se, but my feelings are far from friendly. Writing after numerous assassinations of prominent figures in the civil rights struggle in the 1960s, a struggle that united Baldwin and John Lewis as they appeared together on several high-profile marches, Baldwin commented upon his own faltering faith in the future of the United States, lamenting that "something has altered in me, something has gone away."

Baldwin pointed out that "incontestably, alas, most people are not, in action worth very much; and yet every human being is an unprecedented miracle. One tries to treat them as the miracles they are, while trying to protect oneself against the disasters they've become." Something has altered in me as well after witnessing the 6 January insurrection in Washington DC. Something has gone far away after watching the marauders peacefully escorted out once their vulgar debauch had subsided; going further away still upon seeing congressional representatives whose very lives were threatened failing to hold accountable their colleagues who whipped up such misguided fury. As I write this, Republican obstinacy festers still. It was bad enough that hours after the attack more than one hundred members of the House voted against certifying the election results; that many are now actively working to dismiss the attack on Congress and whitewash over it as merely an act of protest is a shameless dereliction of duty, conscience, and history. In his first inaugural address in 2009, Barack Obama pledged that we should extend our hands to those on the wrong side of history, if they were willing to unclench their 
fists. ${ }^{10}$ Amid talk of bridge building and high rhetoric about coming together in some putative middle, I feel we'd do just as well to remember that a divide can also be bypassed via a tunnel. If the intractable among us won't meet us halfway, then it's high time we went around them.

Alas, I fear my provincial Americanness must be showing. I'm feeling more than a bit tribal and polarized myself as of late and I'm feeling most American in the moments when I have the least interest in compromise and the most investment in "justice." Terry K. Aladjem has written that when Americans talk about justice, "they want something angry and punitive."11 In his essay "Stranger in the Village" from 1953, Baldwin wrote that "people are trapped in history and history is trapped in them."12 I'd like to tell you that they are wrong, but I've watched too many Westerns and lived too long in this democracy to deny their truths. I'm no stranger in this village; I, too, am a product of the culture in which I was raised. I'd be lying to you, and myself, were I to deny that each time charges are announced for another participant in the January insurrection I scoff at the absence of charges for sedition, treason, and terrorism against the mob of mutineers. Focusing unduly on the American scene presents its own conundrum too in a journal devoted to a man as cosmopolitan as Baldwin, for James Baldwin Review seeks to expand our international readership. As of this volume, we've had visitors to our open access website from 80 different countries around the world, a readership we hope to expand further, not alienate with additional focus on the "exceptionalism" of America. The fragility of American democracy, though, bodes ill for the whole world if we let it falter still.

Forgive me, dear reader, as I'm having some troubles tying this all together. For one, to even make a tentative list of all that has transpired since last I penned the introduction to James Baldwin Review is bound to be exhausting for us both, and yet not nearly exhaustive enough. Rarely does Shakespeare get accused of understating things, but I've selected our first epigraph from King Lear as a nod to all that we've been through this past year. Old or young, I'd say, will never see as much nor have a year lived so long as 2020. There are too many threads upon which to comment. When you have this many threads, your garment is just as likely to be a Gordian snarl of knots as it is to be a beautifully, luxuriously dense weave of 500 strands of the finest Egyptian cotton. Finally, I'll acknowledge that as I write this I'm having trouble focusing on the task at hand chiefly because I'm also simultaneously switching between five different browser windows, constantly refreshing the same webpage in a hexagonal dance of resubmitting the same medical info and the same zip codes, desperately trying to secure my spot in line for a vaccine.

Let's focus, then, on a notion Baldwin seems to have misjudged, the strength of our social bond. Not to say that he "got it wrong," exactly, but to note that the times and circumstances have fundamentally, paradigmatically changed since he wrote. I'm not suggesting that he should somehow have seen the future with which we grapple, nor be faulted for not anticipating the fourth industrial revolution. Rather, I submit that when we bring the power of his words to bear on our own moments, unpacking the contextual, historical distances between us can be especially 
illuminating. Baldwin's long essay No Name in the Street (1972) concludes with a gambit about one's desire to live in harmony among one's fellow citizenry:

A person does not lightly elect to oppose his society. One would much rather be at home among one's compatriots than be mocked and detested by them. And there is a level on which the mockery of the people, even their hatred, is moving because it is so blind; it is terrible to watch people cling to their captivity and insist on their own destruction. ${ }^{13}$

This is both profoundly true, in the elemental human sense of our fear of alienation and desire to be connected, and also unhelpfully bound to the time in which Baldwin first penned it. Simply put, the technological revolution since he wrote this in 1972 means that today, in a mash of posts, one can quite easily oppose one's society; what's more, one can do so without much consequence.

For the opposition Baldwin speaks of occurred in a sphere far more public, far more accountable, than our own online forums where anonymity and isolation reign. In 1972, to be oppositional might mean that you would be shunned, isolated and apart from your peers. Taken further, you might be branded a "radical" and lose privacy due to surveillance. Kept at a distance by leaders during the civil rights movement, spurned by Black Power-in both cases because of his sexuality-and harassed by the FBI, Baldwin would surely have known this. But when you're already isolated and anonymous, when your privacy has already been freely traded for access to platforms, what's one got to lose by being oppositional in 2021? A few social media followers, perhaps? The sad fact is you may well stand to gain quite a bit. Opposition, after all, courts offense, offense begets attention, and attention generates advertising revenue. Certainly you needn't worry about any legal consequences, for you can always resort to claiming your opposition, no matter how outlandish, is merely "opinion." You're not denying reality, you're "simply asking questions." Commit yourself to being oppositional enough, and you might be asked to co-host a show with Tucker Carlson or fill Rush Limbaugh's now vacant talk radio space, to say nothing of the conspiratorial corners of the internet.

It's a sad irony that this same long essay by Baldwin, his most sobering look at the failure of the country to heed the warnings of the civil rights era, begins with an epigraph from an African American spiritual, what he terms in the book a "slave song," with the refrain, "If I had-a-my way I'd tear this building down." ${ }^{14}$ Though the January 2021 coup attempt failed, the dystopian desires so brazenly displayed have been too easily dismissed. Considering America's ills, we are sadly still stuck, as Baldwin noted in 1969, "believing that the empty and criminal among our children are the result of some miscalculation in the formula (which can be corrected); that the bottomless and aimless hostility which makes our cities among the most dangerous in the world is created, and felt, by a handful of aberrants." 15 Some take solace in the idea that the looters were led astray, writing and pontificating about "the big lie," but the harsh truth is that Donald Trump received more than seventy million votes in November. Four years of a monstrously 
misleading administration and half a million deaths from a mismanaged pandemic, and yet close to half of the voters voted for more of the same. That so many refused to accept the results, boorishly breaking into the Capitol in bizarre costumes in pursuit of an absurd premise, a pursuit that left more than 100 injured and five dead, should give us every reason to calculate with a different formula.

At the time of this writing, deaths due to COVID-19 are nearing 600,000 in the US, over 3 million worldwide. ${ }^{16}$ Hunkered down at home, weve learned a lot of medical terminology this year. The term "comorbidity" refers primarily to the existence of two simultaneous ailments. This coexistence is not an issue of causality; it is an issue of consequences. Whether we term them conditions, disorders, or diseases is less important than the notion that more than one of these, in combination, is more likely to lead to serious illness or death. I'd like to propose that we examine the political impact of Trump and his hold on not just the public but especially the Republican party with the same terminology. Not an issue of cause or symptom, but as a comorbidity. Was it Trump's racism and disdain for authority that called out to his voters and the politicians and pundits that did his bidding, or was he simply a witless but all too willing accomplice to America's persistent white supremacy and willed ignorance? That, to me, is less important than the fact, which I perceive to be as plain as day, that this combination, these comorbidities in the American political and governmental system, are making our democracy measurably ill. One can only hope that should the morbidity turn mortal it will mean the death of so-called "Republican" politics in America, and not of the American republic.

Comorbidity also may be a useful lens through which to understand the January insurrection, as we're forced now more than ever before to ponder the impact of social media on public discourse and democracy. Are the antisocial impetuses revealed in the meteoric rise of social media platforms amplifying or merely revealing our tendencies to separate into cordoned-off, warring camps? Surely the scions of social media would prefer to lay the blame at our feet and claim that they are merely providing "what the users want." Messrs Zuckerberg, Pichia, and Dorsey have all repeatedly proclaimed so, whenever Facebook, Google, or Twitter are brought before Congress concerning the impact of their platforms. Resisting regulation at every turn, they either push responsibility onto users or claim they're unable to do anything about the beasts they've unleashed. Say what you will about the desire to play God and cheat death, but at least Dr. Frankenstein had the decency to chase his monster to the ends of the earth when it got free and started killing people.

Baldwin, speaking of the television Western Gunsmoke, rightly points to the inseparability between culture and society, undermining the notion that art or society "reflects" one or the other, and insisting that they are, instead, intertwined:

I am less appalled by the fact that Gunsmoke is produced than I am by the fact that so many people want to see it ... The people who run the mass media and those who consume it are really in the same boat. They must continue to produce things they do 
not really admire, still less love, in order to continue buying things they do not really want, still less need ... The trouble is that serious things are handled (and received) with the same essential lack of seriousness. ${ }^{17}$

Our current media culture is far more diverse and diversified-two different things, after all - than the broadcast media apparatus that reigned when Baldwin wrote this essay in 1959, a time when there were only a handful of channels, and Westerns like Gunsmoke accounted for an inordinate amount of programming. In our narrowcasting realm of streaming services and niche selections, though, the paradigm is eerily similar. One can be forgiven for looking at Mr. Andy Cohen's television oeuvre with the same appalled apprehension at the state of our "culture" industry, to say nothing of the absurdities paraded about as "news." All this before we even begin to see the effects of what Baldwin aptly diagnosed as an "essential lack of seriousness" be played out as the rejection of mask-wearing mandates, hesitancy over a vaccination that will save not only lives but entire economic orders, or the outright denial of contagion itself during a pandemic.

Though he could not have envisioned the paradigmatic shifts in our media environments since 1972, Baldwin seems eerily prescient about the calamities to befall us when we deny the fulness of our complex humanity. In his first major essay, "Everyone's Protest Novel," an attack on Richard Wright that launched his career even before his first novel was published, Baldwin worried about a zeal for categorization leading to confusion that is worth an extended quote:

Our passion for categorization, life neatly fitted into pegs, has led to an unforeseen, paradoxical distress; confusion, a breakdown of meaning. Those categories which were meant to define and control the world for us have boomeranged us into chaos; in which limbo we whirl, clutching the straws of our definitions. The "protest" novel, so far from being disturbing, is an accepted and comforting aspect of the American scene, ramifying that framework we believe to be so necessary. Whatever unsettling questions are raised are evanescent, titillating; remote, for this has nothing to do with us, it is safely ensconced in the social arena, where, indeed it has nothing to do with anyone, so that finally we receive a very definite thrill of virtue from the fact that we are reading such a book at all. This report from the pit reassures us of its reality and its darkness and our own salvation ... But unless one's ideal of society is a race of neatly analyzed hard-working ciphers, one can hardly claim for the protest novels the lofty purpose they claim for themselves or share the present optimism concerning them. They emerge for what they are; a mirror of our confusion, dishonesty, panic, trapped and immobilized in the sunlight prison of the American dream. ${ }^{18}$

Writing from Paris in the late 1940s, Baldwin here aptly captures the encapsulated existences of our cordoned-off, online lives. The unparalleled connectivity we experience in an utterly mediated reality has paradoxically led us to be less connected than ever before. For most of our connections are meted out by a set of algorithmic designs that few of us explicitly consented to and even fewer of us understand. The "ideal" society Baldwin warns of here is precisely the ideal of a 
well-functioning algorithm: neatly broken down into discrete units with predictable outputs. What's more, the algorithms that populate our media spheres were designed to capture most of all our attention. And, to put it mildly, we are hooked. As communication theorist and Obama campaign strategist Michael Slaby notes in his manifesto for changing the trajectory of these platforms, For All the People, this addiction is by design:

These systems are intended to be habit forming ... They are designed with feedback loops meant to prey on our brain chemistry for rewards and with outrage to keep our attention. They are configured to keep us clicking on more and more content, regardless of whether we are informed or satisfied. Being informed or satisfied is not the goal of these systems-it's not how they are optimized. ${ }^{19}$

To put it simply, as long as we stay logged on the ad revenue piles up. None of this, mind you, is an accident; it has been designed this way. On purpose. For profit. This cannot be overstated. The predictability of the unit and the output feed back upon each other in a loop or echo that is no less predictable, and therefore all the more profitable.

Were it only profits being extracted, the need for modification might not be so dire. When the loop closes in upon itself, authority and expertise are not simply no longer needed, they are, more worrisome still, a burden to the smooth flow of algorithmic sorting. What once was knowledge or wisdom is now noise, friction, a hindrance. The distinction between information and disinformation falls apart when the only marker of impact is popularity. As Baldwin put it, the unforeseen result is "confusion, a breakdown of meaning" as we are "boomeranged into chaos." The chaos is not merely metaphorical, for Slaby usefully points out that the consequences of such indistinguishability are not just dire, they are downright deadly:

As more and more of our content consumption moves toward online streams and feeds, the platforms benefit more-in terms of maximized attention and continuous engagement-from the indistinguishability of credible versus incredible content than from accuracy ... In addition to crumbling trust, the failure of our systems to help us understand and distinguish credible information also results in a decrease in the value of expertise that society needs to function. ${ }^{20}$

Whether it is the promulgation of misinformation about public health, further polarization and division, the lack of a common story to unify, or a shared aim for which to strive, the "price of the ticket" we've paid for all this putatively "free" content is proving, alas, to be rather expensive. Poisoned bread, indeed.

The seventh volume of James Baldwin Review contains a mixture of tone, approach, and topic as we continue to strive to deliver material to stimulate appreciation and 
debate about the writing and impact of our chief subject. Our volume begins with a "Feature Essay" by the esteemed and inimitable Ed Pavlić entitled "Indisputably Available': The Texture-Gendered, Sexual, Violent-of James Baldwin's Southern Silences." Prompted by his reading of Colson Whitehead's Pulitzer Prize-winning novel The Nickel Boys (2019), which is set in Tallahassee, FL, during the 1950s and 1960s, Pavlić presents here an in-depth look at Baldwin's own visit to Tallahassee in May 1960. Considering Baldwin's writings about the South, especially the 1960 essay “They Can't Turn Back," Pavlić puts forth the missing names of Black women in the places marked and unmarked by Baldwin - notably but not limited to Girvaud Roberts, Dorothy Tookes, and Patricia Stephens Due-and puts the May 1959 sexual assault of Betty Jean Owens on the historical map. Pavlićs exploration of issues of race, gender, sex, and violence for their intertwined impacts on historical, and some contemporary, writing offers a deeper consideration of Baldwin's work and the history which he drew upon and to which he contributed so profoundly.

Volume 7 of James Baldwin Review presents our first group of guest-edited essays, concentrating our attention on Baldwin and film, considered broadly, in a special section edited by Robert Jackson entitled "Finding Work for the Devil." The essays in this section, from Robert Jackson, Karen Thorsen, D. Quentin Miller, Hayley O'Malley, and Peter Lurie, grew out of a panel hosted by JBR at the Modern Language Association's meeting in Seattle in January of 2020. As Jackson notes in his introduction to the section, Baldwin's relationship with film throughout his life was complicated:

Film is such a big topic in Baldwin's life and career that it can almost be invisible at times, like geological time or climate change or some other pattern whose scale renders it invisible ... Baldwin's relationship with film, meanwhile, is not just one thing; it takes many forms, and it changes a great deal over the course of his life.

From Thorsen's remembrance of her lunch with Baldwin in 1986 to O'Malley's deep dig through archival riches, from Miller's innovative reading of The Devil Finds Work as a love story to Lurie's examination of the impacts Baldwin's cinematic visions continue to make in current film, this special, guest-edited section of James Baldwin Review presents a close focus on a specific topic in Baldwin's life, work, and legacy.

Our Graduate Student Award-winning essay, “In the Name of Love': Black Queer Feminism and the Sexual Politics of Another Country," comes to us from Matty Hemming of the University of Pennsylvania. Hemming explores the sexual politics of Baldwin's 1962 novel from a Black queer feminist perspective, arguing that this critical lens allows us to de-prioritize white gay male eroticism and pursue analyses of a broader range of erotic scenes, thereby reframing Another Country as less an idealization of gay male intimacy, reading it, instead, as a troubling, unsettling vision of sex within, as Hemming puts it, a "messy terrain of pleasure, pain, and political urgency."

The "Dispatches" section includes two interviews and a review. William J. Maxwell interviewed Bill Mullen about Mullen's latest book, James Baldwin: Living 
in Fire (2019), and their discussion naturally includes a consideration of Baldwin's internationalism and his relevance to the current pitfalls-and possibilitieswithin our contemporary racial moment. The second interview was conducted over email by JBR editors Douglas Field and Justin A. Joyce with James Campbell. Campbell, whose biography of Baldwin, Talking at the Gates, will be reissued in an expanded edition later this year, provides readers with an expansive consideration of a number of topics and time periods. The resulting interview is, perhaps, the record of a man of letters, whose career of reading and writing, I hazard, we all might wish to emulate. Our "Dispatches" closes with a review essay by Herb Boyd, "White Lies Matter," wherein Boyd evaluates Eddie S. Glaude, Jr.s best-selling Begin Again: James Baldwin's America and Its Urgent Lessons for our Own (2020) against several other recent works such as Bill Mullen's James Baldwin: Living in Fire and Nicholas Buccola's The Fire Is Upon Us (2019).

James Baldwin Review is very excited to premiere in this volume our first set of creative works. Swedish writer Aleksander Motturi presents us with "The Fire Inside," translated for $J B R$ by award-winning translator Kira Josefsson, a creative spin on the infamous meeting between Baldwin and then US Attorney General Robert Kennedy in 1963. Motturi's piece is followed by a contribution from Maureen Kelleher, private detective and advocate for prisoners wrongly sentenced to death. "Baldwin's Perfect Storm" is a creative reimagining of Baldwin's suicidal depression upon his release from a brief stint in a Parisian jail in 1949. We hope these first creative pieces in $J B R$ will not only provoke our readers' imaginations but also generate interest and further submission of creative works for future volumes.

As many of you may have heard, we lost an esteemed colleague in 2020 with the passing of Cheryl Wall. James Baldwin Review, with the generous coordination of Cora Kaplan, has collected here numerous tributes to Cheryl's memory, her impact, and her friendship in an In Memoriam tribute. Professor Wall didn't simply change the course of African American literary studies with her pioneering work on Black women's fiction-especially that of Zora Neale Hurston-she also touched countless lives through her generous mentorship and inspired teaching. We hope to honor her legacy here.

Our seventh volume finishes with our bibliographic essay, which comes to us from Terrance Dean. Reading works on Baldwin from 2017 to 2019, Dean tracks the significance of Baldwin for the Black Lives Matter movement and our growing need for police reform in conjunction with a revaluation of the lives of racial and ethnic minorities within the oppressive systemic biases of American social and political life.

This year's cover comes to us from Brooklyn-based artist Rico Gatson, whose stunning mural installations adorn the recently remodeled 167th St. subway station in New York City. The Baldwin mural, based off of a photograph by Steve Shapiro, is one of eight murals drawn from Gatson's earlier museum installation, "Icons." The other murals at the Bronx station by Gatson celebrate Gil Scott Heron, Audre Lorde, Celia Cruz, Justice Sonya Sotomayor, Reggie Jackson, Tito Puente, and Maya Angelou. Aptly entitled "Beacons," these murals stand as prominent testaments to the 
power of cultural and artistic icons to lead and catalyze change and action through their exemplary lives and works. James Baldwin Review is grateful to Mr. Gatson and Mr. Shapiro for their generous permission to feature this inspiring public art. Like a lighthouse showing the way safely to shore, or a signal fire lighting the darkness, beacons of hope like James Baldwin can help ensure we are walking in the right direction on whatever paths our journeys create.

Pondering the disarray and discordance wrought by the paradigm shift in our communications and connections, looking to Baldwin's searing witnessing as a beacon in our present darkness, I take solace in Baldwin's notion of being "boomeranged." As I understand it, a boomerang comes back to the thrower at the end of its arc. It's a weapon, after all, a tool intended to wound or kill, but what makes it unique and storied is that after riding the wind on its deadly path, it returns to the point of origin. Unlike other projectiles, the boomerang, that is, comes back. The elliptical path is somewhat predetermined but we have the chance to catch it at a different point. Though we may have been thrown into chaos, perhaps by walking a step toward the arc of the tools and weapons we've deployed, to meet them in a different place from whence we began, we might have the chance to come back. To what, though, depends upon us.

Each of us, then, has much work to do to ensure that the arc of the weapon bends toward not more death or destruction, not more disinformation and division, but instead toward a different use for the tools of our time, in line with the oft-quoted line from Martin Luther King about the arc of the moral universe bending toward justice. Speaking on the occasion of John Lewis's sixty-fifth birthday, Barack Obama noted that this arc needs our work:

It doesn't bend on its own. It bends because we help it bend that way ... [because] thousands of ordinary Americans with extraordinary courage have helped it bend that way ... we continue to progress as a people because they inspire us to take our own two hands and bend that arc. ${ }^{21}$

As my colleague Julian Hayter has put it, "things done on purpose must be undone purposefully."22

The purposes before us are many-police reform, expansion of voting rights and access, healthcare reform, climate change and energy reform, gun control, renewing our commitments to not just scientific expertise but higher education as wellbut in closing I'd like to bring us back to where we began our journey. One of the striking parts about John Lewis's story is the presence of the lone figure of authority, Aunt Sevena. She's the "adult in the room," you see, and we've been hearing a lot about these adults as of late. How the adults in the room would prevail over irresponsible notions and instill order and calm amid the chaos. Over and again we were assured that the "adults in the room" would temper Trump's tantrums. Instead, they were simply replaced. Whenever one of the "adults" ran counter to impish impulses, a more malleable minion was ushered in to take their place.

As Baldwin pointed out in The Fire Next Time (1963), "a civilization is not destroyed by wicked people; it is not necessary that people be wicked but only that 
they be spineless."23 The cumulative effect of such a revolving door in so esteemed an office as the White House was that at any one time which adult in the room was supposed to be the voice of reason was unclear, to both the greater public and the other grown-ups in the West Wing. Categorically unchecked, is it any wonder the "child" grew unrulier still? He tried to cheat the election by pressuring numerous officials to overturn results, cried "foul" when he didn't win, and spread false information nearly as fast as specious lawsuits. When all these attempts to rig the game in his favor came up short, are we really surprised that he ultimately resorted to inciting a riot and a revolt, like a brat smashing his toys?

I find solace and, it must be admitted, a bit of hope near the end of our journey, in the image of conscience and courage presented by Aunt Sevena as she guided the children in her care during the windstorm. Certainly, there are children about still who need such courage from us, for the winds have not yet ceased to blow. Baldwin wrote many times about innocence and children-not at all the same thing-often with variations on a central thesis, that "a child cannot afford to be fooled." ${ }^{4}$ Writing for Esquire in 1980, he elaborates:

Children, I submit, cannot be fooled. They can only be betrayed by adults, not fooled - for adults, unlike children, are fooled very easily, and only because they wish to be ... no child can fool another child the way one adult can fool another. ${ }^{25}$

After the year we've come through, I'd venture that America, young and old, can no longer afford to fool ourselves and each other. For whenever this present storm may pass, another will surely rise, threatening to lift again the corners of our house. In these moments, we will need to heed Aunt Sevena's instruction. Each of us, whether we dwell in the American house or no, whether or not we are the designated "adult" in the room, will need to move at least close enough to grasp one another's hand and walk together. Whichever path you walk to secure a healthier, more unified, and more just future, walk well, friends, and walk with the wind.

Grosse Pointe Park, MI, 1 May 2021

\section{Notes}

1 William Shakespeare, King Lear, Act 5, scene 3, final lines spoken by Edgar.

2 James Baldwin, No Name in the Street (1972) (New York, Vintage, 2000), p. 192.

3 John Lewis, Walking with the Wind: A Memoir of the Movement (New York, Simon and Schuster, 1998), p. xvi.

4 Ibid., pp. xvi-xvii.

5 James Baldwin, "Letter to Jay Acton," qtd. in I Am Not Your Negro (Compiled and Edited by Raoul Peck) (New York, Vintage, 2017), p. 5.

6 Toni Morrison, qtd. in Timothy Greenfield-Sanders (dir.), Toni Morrison: The Pieces I Am (USA, Perfect Day Films, 2019).

7 Abraham Lincoln, “Inaugural Address, March 4, 1861," https://millercenter.org/ the-presidency/presidential-speeches/march-4-1861-first-inaugural-address (accessed 23 April 2021). 
8 Baldwin, No Name, p. 9.

9 Ibid., p. 10.

10 Barack Obama, "A New Era of Responsibility," First Inaugural Address, Washington DC, 20 January 2009, in We Are the Change We Seek: The Speeches of Barack Obama, ed. E. J. Dionne, Jr., and Joy-Ann Reid (New York, Bloomsbury, 2017), p. 102.

11 Terry K. Aladjem, The Culture of Vengeance and the Fate of American Justice (New York, Cambridge University Press, 2008), p. 3.

12 James Baldwin, "Stranger in the Village" (1953), in Collected Essays, ed. Toni Morrison (New York, Library of America, 1998), p. 119.

13 Baldwin, No Name, pp. 194-5.

14 Ibid., n.p.

15 James Baldwin, "Mass Culture and the Creative Artist: Some Personal Notes" (1969), in The Cross of Redemption: Uncollected Writings, ed. Randall Kenan (New York, Pantheon, 2010), p. 5.

16 Statistics from the Johns Hopkins Coronavirus Resource Center, https://coronavirus. jhu.edu/map.html (accessed 23 April 2021).

17 Baldwin, "Mass Culture and the Creative Artist," pp. 4-5.

18 James Baldwin, "Everybody's Protest Novel” (1949), in Notes of a Native Son (New York, Beacon Press, 1992), p. 19. I'm indebted to the Quilting Points reading group, led by Joseph Genchi, Izzy Jenkinson, and Craig McDonald at the University of Leeds, for inviting me to participate in their discussions during 2021. Izzy Jenkinson, in particular, deserves credit here for first bringing the contemporary pertinence of this part of Baldwin's essay to my attention.

19 Michael Slaby, For All the People: Redeeming the Broken Promises of Modern Media and Reclaiming our Civic Life (New York, Disruption Books, 2021), pp. 168-9.

20 Ibid., pp. 88-9.

21 Barack Obama, “'How Far We've Come,' Remarks at John Lewis's Sixty-fifth Birthday Gala, Atlanta, GA, Feb 21, 2005," in Dionne, Jr., and Reid (eds.), We Are the Change We Seek, p. 20.

22 I first heard this from Hayter as part of a community discussion sponsored by the Oklahoma Center for the Humanities on Carol Anderson's book White Rage on 4 February, 2021. I'm using this quote here with Dr. Hayter's permission.

23 James Baldwin, The Fire Next Time (1963), in Morrison (ed.), Collected Essays, p. 318.

24 James Baldwin, "If Black English Isn't a Language, Then Tell Me What Is" (1979), in Morrison (ed.), Collected Essays, p. 783.

25 James Baldwin, “Dark Days" (1980), in Morrison (ed.), Collected Essays, p. 794.

\section{Works Cited}

Aladjem, Terry K., The Culture of Vengeance and the Fate of American Justice (New York, Cambridge University Press, 2008).

Baldwin, James, "Dark Days" (1980), in Collected Essays, ed. Toni Morrison (New York, Library of America, 1998), pp. 788-98.

"Everybody's Protest Novel" (1949), in Notes of a Native Son (New York, Beacon Press, 1992), pp. 11-18.

The Fire Next Time (1963), in Collected Essays, ed. Toni Morrison (New York, Library of America, 1998), pp. 286-347. 
2017).

I Am Not Your Negro (Compiled and Edited by Raoul Peck) (New York, Vintage,

"If Black English Isn't a Language, Then Tell Me What Is" (1979), in Collected Essays, ed. Toni Morrison (New York, Library of America, 1998), pp. 780-3.

"Mass Culture and the Creative Artist: Some Personal Notes" (1969), in The

Cross of Redemption: Uncollected Writings, ed. Randall Kenan (New York, Pantheon, 2010), pp. 3-6.

No Name in the Street (1972) (New York, Vintage, 2000).

"Stranger in the Village" (1953), in Collected Essays, ed. Toni Morrison (New

York, Library of America, 1998), pp. 117-29.

Greenfield-Sanders, Timothy (dir.), Toni Morrison: The Pieces I Am (USA, Perfect Day Films, 2019).

Johns Hopkins Coronavirus Resource Center, https://coronavirus.jhu.edu/map.html (accessed 23 April 2021).

Lewis, John, Walking with the Wind: A Memoir of the Movement (New York, Simon and Schuster, 1998).

Lincoln, Abraham, "Inaugural Address, March 4, 1861," https://millercenter.org/thepresidency/presidential-speeches/march-4-1861-first-inaugural-address (accessed 23 April 2021).

Obama, Barack, “A New Era of Responsibility," First Inaugural Address, Washington DC, 20 January 2009, in We Are the Change We Seek: The Speeches of Barack Obama, ed. E. J. Dionne, Jr., and Joy-Ann Reid (New York, Bloomsbury, 2017), pp. 96-105.

"'How Far We've Come,' Remarks at John Lewis's Sixty-fifth Birthday Gala, Atlanta, GA, Feb 21, 2005," in We Are the Change We Seek: The Speeches of Barack Obama, ed. E. J. Dionne, Jr., and Joy-Ann Reid (New York, Bloomsbury, 2017), pp. 14-20.

Slaby, Michael, For All the People: Redeeming the Broken Promises of Modern Media and Reclaiming our Civic Life (New York, Disruption Books, 2021).

\section{Contributor's Biography}

Justin A. Joyce is one of the founding editors of James Baldwin Review and the journal's current managing editor, and he is Research Director at The New School. An interdisciplinary scholar of literature and film, his first monograph was Gunslinging Justice: The American Culture of Gun Violence in Westerns and the Law (Manchester University Press, 2018). With Dwight A. McBride, he is the editor of A Melvin Dixon Critical Reader (University Press of Mississippi, 2006), Vincent Woodard's Lambda Literary Award-winning book The Delectable Negro: Human Consumption and Homoeroticism in U.S. Slave Narratives (NYU Press, 2014), and Lindon Barrett's Racial Blackness and the Discontinuity of Western Modernity (University of Illinois Press, 2014). Featured in interviews and discussions on The Humanities on the High Plains podcast, the Maryland Lynching Memorial Project, and on RadioWest, Joyce's writings on Baldwin have also appeared in A Historical Guide to James Baldwin (Oxford University Press, 2009) and James Baldwin in Context (Cambridge University Press, 2019). 